\title{
PELATIHAN PENGEMBANGAN DIGITAL ASSESMENT BAGI GURU SEKOLAH DASAR DI KEPULAUAN SERIBU
}

\author{
Uswatun Hasanah ${ }^{1}$, Edwita ${ }^{2}$, Ahmad Januar ${ }^{3}$ \\ 1,2 Universitas Negeri Jakarta, Indonesia \\ ${ }^{3}$ SDN Cipulir 11 Pagi Jakarta, Indonesia \\ ${ }^{1}$ uswatunhasanah@unj.ac.id
}

\begin{abstract}
Digital assesment is considered to provide more accurate (objective) results according to predetermined criteria. This community service activity aims to provide solutions to partner schools that have limitations in implementing digital assessment. In this case the seesaw can be used as an alternative to digital-based portfolio assessment. Of course, this seesaw is one type of authentic assessment that supports competencies in the 2013 curriculum. With this service activity, it is hoped that teachers can apply digital assessment to all learning appropriately so that it can improve the quality of learning outcomes. The training participants consisted of 107 teachers spread across the Thousand Islands area. This activity is carried out online using the zoom meeting application. The service results show that $85 \%$ of teachers understand the concept of authentic assessment, development of digital assessment, and how to develop digital-based instruments. This service activity can contribute to and support the government in advancing the quality of learning for elementary schools. The implementation of digital assessment which is carried out authentically will make the learning process more meaningful and quality.
\end{abstract}

Keywords: digital assessment; seesaw; quality of learning

\begin{abstract}
Abstrak
Penilaian berbasis online (digital assessment) dinilai lebih memberikan hasil yang akurat (objektif) sesuai dengan kriteria yang telah ditentukan. Kegiatan pengabdian masyarakat ini bertujuan untuk memberikan solusi kepada sekolah mitra yang memiliki keterbatasan dalam mengimplementasikan digital asessment. Dalam hal ini seesaw dapat dijadikan alternative peniaian portofolio berbasis digital. Tentunya seesaw ini salah satu jenis penialan autentik yang mendukung kompetensi dalam kurikulum 2013. Dengan adanya kegiatan pengabdian ini, diharapkan guru dapat mengaplikasikan digital asessment pada semua pembelajaran secara tepat sehingga dapat meningkatkan kualitas hasil pembelajaran. Peserta pelatihan terdiri dari 107 guru yang tersebar di wilayah Kepulauan Seribu. Kegiatan ini dilakukan secara daring menggunakan aplikasi zoom meeting. Hasil pengabdian menunjukkan bahwa $85 \%$ guru memahami konsep penilaian autentik, pengembangan digital assesment, dan cara mengembangkan instrument berbasis digital. Kegiatan pengabdian ini dapat memberikan kontribusi dan mendukung pemerintah dalam memajukan kualitas pembelajaran bagi sekolah dasar. Penerapan digital assessment yang dilaksanakan secara autentik akan membuat proses pembelajaran menjadi lebih bermakna dan berkualitas.
\end{abstract}

Kata Kunci: digital assessment; seesaw; kualitas pembelajaran

Submitted: 2020-09-04 Revised: 2020-09-15 Accepted: $2020-09-17$

\section{Pendahuluan}

Menghadapi situasi pembatasan sosial berskala besar (PSBB), Kementerian Pendidikan dan Kebudayaan telah menerbitkan Surat Edaran Nomor 4 Tahun 2020 tentang Pelaksanaan Pendidikan Dalam Masa Darurat Coronavirus Disease (Covid-19). Dalam hal ini, kegiatan pembelajaran di sekolah sementara dihentikan dan dialihkan pada 
pembelajaran di rumah secara daring. Pada pembelajaran online, guru dan siswa akan terhubung secara virtual. Guru diminta melaksanakan proses pembelajaran kepada siswa melalui aplikasi yang telah tersedia tanpa mengurangi esensi dari pembelajaran tersebut. Guru dapat memanfaatkan fitur-fitur yang tersedia pada aplikasi pembelajaran online untuk meningkatkan kualitas pembelajaran.

Dalam meningkatkan kualitas hasil pembelajaran, guru perlu memperhatikan seluruh aspek yang terkait dalam pembelajaran. Salah satunya aspek menilai hasil belajar siswa. Jika penilaian yang diterapkan secara efektif dan valid maka luaran yang akan dihasilkan akan berkualitas. Namun sebaliknya, jika penilaian yang diterapkan guru tidak valid dan objektif maka luaran yang dihasilkan menjadi tidak bermakna. Dalam hal pembelajaran online, penilaian pembelajaran juga dilaksanakan secara online. Tentunya penggunaan teknologi dalam melakukan penilaian harus dapat mengukur ketercapaian siswa dalam pembelajaran secara autentik.

Namun pada kenyataannya, sebagian besar guru belum menerapkan penilaian pembelajaran secara optimal. Hal ini dikarenakan keterbatasan mereka menguasai teknologi dalam penilaian pembelajaran. Alhasil, kenyataan yang terjadi kegiatan pembelajaran online yang dilaksanakan hanya sia-sia saja karena tidak adanya proses penilaian yang kontekstual. Banyak keluhan dari para guru dengan keberlangsungan proses ini. Salah satunya terjadi di beberapa sekolah dasar sekitar Kepulauan Seribu, DKI Jakarta. Berdasarkan observasi pra lapangan, guru merasa sulit dalam mengimplementasikan penilaian berbasis online. Mereka berpendapat penilaian berbasis online hanya membuat rumit saja. Padahal Dinas Pendidikan setempat telah mengadakan pelatihan kepada para guru dalam hal penilaian berbasis online (digital asessment). Namun yang terjadi di lapangan, sebagian besar guru belum menguasai system penilaian secara digital. Akibatnya penilaian menjadi beban guru sehingga dikerjakan secara terpaksa dan berdampak negative pada kualitas pembelajaran yang dilakukan.

Dalam kurikulum 2013, penilaian terhadap pembelajaran harus mencakup aspek yang dimiliki siswa baik secara kognitif, afektif, dan psikomotornya. Penilaian adalah istilah yang luas didefinisikan sebagai proses untuk memperoleh informasi yang digunakan untuk membuat keputusan terhadap siswa, kurikulum, program dan sekolah, dan kebijakan pendidikan. Penilaian merupakan bagian integral dari suatu pembelajaran karena itu perlu dilaksanakan secara terpadu dan autentik.

Authentic assessments are function-based and based in a child's routines, as opposed to the above-described conventional assessments, which are the typical normreferenced assessments (de Sam Lazaro, 2017). Sesuai dengan peryataan di atas bahwa penilaian autentik sangat berbeda dengan penilaian konvensional pada umumnya yang hanya mengandalkan pada angka. Penilaian autentik merupakan salah satu bentuk penilaian hasil belajar peserta didik yang didasarkan atas kemampuannya menerapkan ilmu pengetahuan yang dimiliki dalam kehidupan yang nyata di sekitarnya (Ermawati, Siti., \& Hidayat, 2017). Pernyataan tersebut menunjukkan bahwa dalam penilaian autentik, peserta didik dilibatkan secara aktif dan realistis dalam mengevaluasi kemampuan mereka sendiri.

Penilaiaan autentik dapat dilakukan dengan system online. Dalam ujian manual tingkat kecurangan siswa lebih tinggi dibandingkan ujian online assesment, karena 
banyak kemungkinan yang akan terjadi bila ujian dilakukan secara manual, berbeda dengan digital asessment yang mana tingkat kecurangan bisa diminimalisir karena di dalam digital asessment itu siswa tidak bisa sembarangan mengikuti digital asessment begitu saja karena sebelum dilakukan digital asessment siswa harus login satu satu yang mana setiap siswa memiliki user name dan pasword masing masing jadi siswa tidak dapat mengakses ke siswa lain, hanya bisa masuk dalam artian login ke siswa lain untuk mengambil data hasil pekerjaan temannya yang lain. Penilaian berbasis online (digital asessment) dapat meningkatkan kualitas hasil pembelajaran. system penilaian ini sangat efektif dan efisien karena dapat mengukur kemampuan siswa secara objektif dan valid.

Beberapa penelitian yang menyatakan bahwa Digital Asessment dapat mendukung keberhasilan pembelajaran antara (Alfian et al., 2015; Azim \& Khan, 2012; Charoenchai et al., 2015; Ermawati, Siti., \& Hidayat, 2017; Ferita \& Retnawati, 2017; Fitriani, 2017; Hodgman, 2014; Holliday et al., 2015; James \& Casidy, 2018; Kartowagiran \& Jaedun, 2016a, 2016b; Larkin, 2014; Noor et al., 2016; Susani, 2018; Villarroel et al., 2017; Wiggins, 1990). Penelitian berbasis online ini dapat diimplementasikan dengan beberapa aplikasi antara lain quizziz, kahoot, google form dan sebagainya.

Berdasarkan uraian di atas, maka sangat perlu dilakukan pelatihan guru dalam mengimplementasikan digital asessment . Kegiatan ini sangat penting karena berdampak positif dalam mengembangkan kualitas hasil pembelajaran siswa. Dengan adanya pelatihan ini, guru dapat dilatih untuk mengolah system penilaian pembelajaran sehingga hasil penilaian yang dilakukan dapat mencerminkan seluruh aspek perkembangan siswa.

\section{Metode}

Kegiatan pelatihan pengembangan digital assesment dilaksanakan selama dua hari yakni pada hari Senin, 24 Agustus 2020 sampai dengan Selasa 25 Agustus 2020. Setiap harinya, kegiatan dimulai pada pukul 09.00 - 15.00 WIB. Berhubung saat ini masa pandemic covid 19 dan tidak memungkinkan pertemuan tatap muka dengan banyak orang, maka kegiatan ini dilaksanakan secara daring menggunakan aplikasi zoom meeting. Total peserta sebanyak 107 orang. Peserta yang mengikuti pelatihan ini adalah guru sekolah dasar yang tersebar di wilayah Jakarta.

Kegiatan pelatihan ini dilaksanakan dengan melalui 3 tahap yaitu perencanaan, implementasi dan refleksi. Adapun pelaksanaanya adalah sebagai berikut:

a. Tahap 1: Perencanaan

Tim pelaksana membuat perencanaan seperti menyusun surat izin dan surat tugas pengabdian masyarakat, membuat jadwal kegiatan, menentukan sasaran peserta, menyusun materi pelatihan, dan menyusun kegiatan yang akan dilakukan guru-guru disertai perangkat-perangkat instrumen yang diperlukan

b. Tahap 2: Pelaksanaan/implementasi

Kegiatan pelatihan dilaksanakan selama dua hari secara daring melalui aplikasi zoom meeting dari pukul 09.00 sampai dengan pukul 15.00 WIB.

Rincian kegiatannya adalah sebagai berikut:

1) Hari ke-1, pukul 09.00 - 15.00 : Penanaman Konsep "Digital Assesment"

a) Pemberian pemahaman "authenthic asessment"

b) Pengenalan aplikasi assessment berbasis digital 
c) Tutorial mengembangkan "Seesaw"

2) Hari ke-2, pukul $09.00-13.00$ : Implementasi

Setiap peserta diminta mengembangkan instrument tes berbasis digital dengan menyesuaikan dengan kompetensi dasar dan target pencapaian siswa

3) Hari ke-2, pukul 13.00 - 15.00 : Presentasi dan apresiasi

Setiap peserta mempresentasikan hasil pengembangan instrument tes berbasis digital dan peserta yang lainnya dapat memberikan masukan dan tanggapan kepada penyaji

c. Tahap 3: Refleksi dan Evaluasi

Refleksi dilakukan dengan strategi berikut:

1) Narasumber memberikan feedback kepada para peserta pelatihan.

2) Peserta pelatihan menyampaikan hasil refleksinya dengan mengisi angket yang telah disajikan dalam bentuk google form.

\section{Hasil dan Pembahasan}

Kegiatan pengabdian masyarakat ini dilaksanakan secara daring menggunakan aplikasi zoom meeting. Kegiatan ini diikuti oleh 107 peserta yang terdiri dari guru-guru sekolah dasar di wilayah Kepulauan Seribu. Kegiatan ini diawali dengan acara pembukaan oleh Kepala Dinas Pendidikan Provinsi DKI Jakarta yaitu Ibu Nahdiana, M.Pd dan sambutan oleh Koorprodi PGSD FIP UNJ yaitu Dr. Fahrurrozi, M.Pd dan dilanjutkan paparan materi oleh tim pengabdian. Dalam hal ini tim pengabdian terdiri dari Uswatun Hasanah, M,Pd, Dr. Edwita, M.Pd, dan Ahmad Januar, S.Pd. Materi yang akan dijelaskan antara lain konsep penilaian autentik, pengenalan aplikasi digital assessment, sampai pada tutorial membuat instrument test berbasis digital yaitu seesaw. Tentunya ini sangat sesuai dengan kondisi lapangan dimana negara Indonesia akan menjalani kebijakan "new normal" sehingga seluruh lembaga dan instansi khususnya sekolah harus menerapkan pembelajaran secara daring di rumah masing-masing. Oleh karena itu adanya pelatihan pengembangan digital assessment ini akan mempersiapkan para guru dalam menerapkan penilaian secara autentik dan objektif yang dilakukan secara online atau digital.

Pada sesi tanya jawab, para peserta terlihat aktif bertanya dan memberikan respon terhadap materi yang diberikan. Berbagai pertanyaan muncul terkait dengan aplikasi seesaw seperti "apa yang menjadikan seesaw sebagai alternative penilaian autentik?

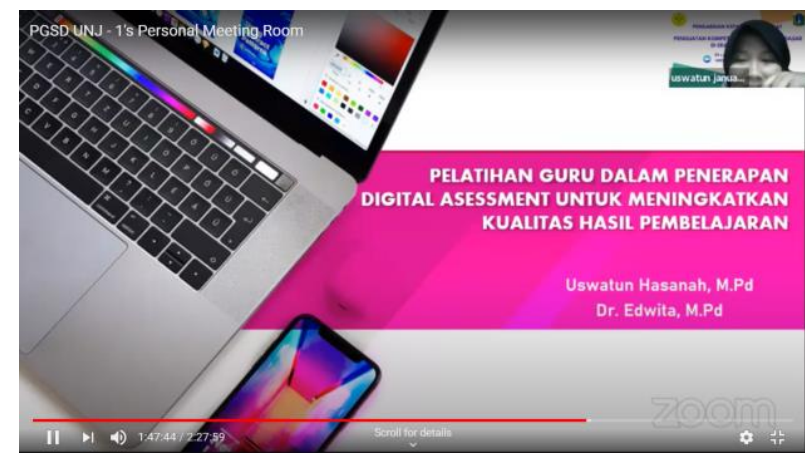

Gambar 1. Narasumber memaparkan materi pengabdian 
Hakikatnya seesaw merupakan salah satu platform penilaian autentik yang dapat digunakan di masa pandemic ini. Seesaw ini merupakan salah satu alternative penilaian portofolio secara digital (Alimuddin, 2014). Pada seesaw, siswa dapat mengupload hasil karya dan produk-produkhasil pembelajaran ke dalamnya sehingga guru dapat menilainya secara keseluruhan. Disamping itu pada seesaw, selain kita mengajar siswa, kita juga dapat menjalin komunikasi dengan anggota keluarga mereka. Hal ini dapat menjadikan kegiatan pembelajaran digital lebih bermakna karena siswa dilatih secara seimbang oleh orang tua dan guru (Gaylord-Opalewski \& O'Leary, 2019). Penilaian portofolio merupakan kegiatan penilaian yang dilakukan dengan menggunakan bukti-bukti hasil belajar (evidence) yang relevan dengan kompetensi keahlian yang dipelajari. Evidence tersebut dapat berupa karya peserta didik (hasil pekerjaan) dari proses pembelajaran yang dianggap terbaik, atau bentuk informasi lain yang terkait dengan kompetensi keahlian tertentu.

Portofolio adalah kumpulan hasil karya seorang peserta didik, sebagai hasil pelaksanaan tugas kinerja yang ditentukan oleh guru atau oleh peserta didik bersama guru, sebagai bagian dari usaha mencapai tujuan belajar, atau mencapai kompetensi yang ditentukan dalam kurikulum. Jadi, tidak setiap kumpulan karya seorang peserta didik disebut portofolio. Portofolio digunakan sebagai instrumen penilaian atau salah satu komponen dari instrumen penilaian, untuk menilai kompetensi peserta didik, atau menilai hasil belajar peserta didik. Sebagai instrumen penilaian, portofotio; difokuskan pada (dokumen tentang kerja siswa yang produktif, yaitu 'bukti' tentang apa yang dapat dilakukan oleh siswa, bukan apa yang tidak dapat dikerjakan (dijawab atau dipecahkan) oleh siswa. Bagi guru, portofolio menyajikan wawasan tentang banyak segi perkembangan siswa dalam belajarnya: cara berpikirnya, pemahamannya atas pelajaran yang bersangkutan, kemampuannya mengungkapkan gagasangagasannya, sikapnya terhadap mata pelajaran yang bersangkutan, dan sebagainya.

Berikut tampilan seesaw :

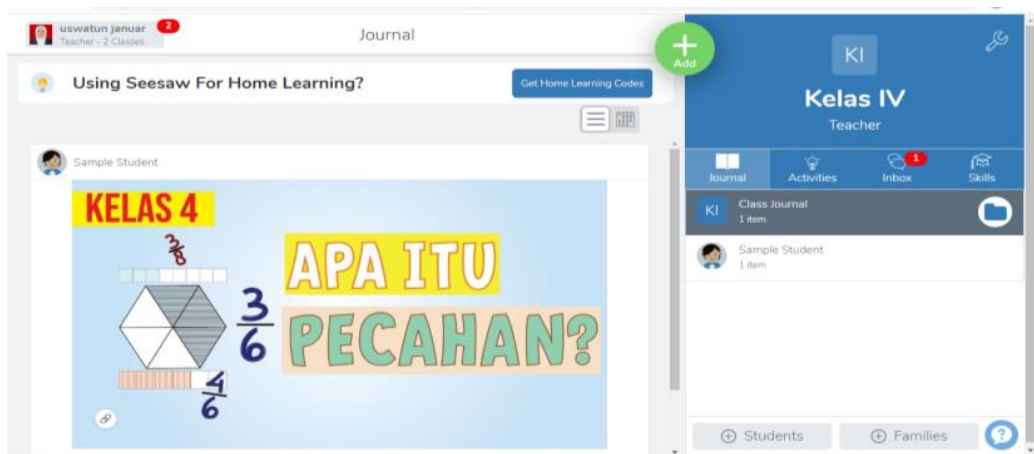

Gambar 2. Tampilan seesaw

Penilaian Portofolio yang terdapat pada seesaw bukan sekedar kumpulan hasil kerja siswa, melainkan kumpulan hasil siswa dari kerja yang sengaja diperbuat siswa untuk menunjukkan bukti tentang kompetensi, pemahaman, dan capaian siswa dalam mata pelajaran tertentu. Portofolio juga merupakan kumpulan informasi yang perlu diketahui oleh guru sebagai bahan pertimbangan dalam menentukan langkah-langkah perbaikan pembelajaran, atau peningkatan,belajar siswa. Dengan demikian seesaw dijadikan sebagai alternative penilaian autentik karena berbasis portofolio. 
Selanjutnya, terdapat peserta yang bertanya, jenis karya apa saja yang dapat diupload ke dalam seesaw? Seesaw memiliki fitur "jurnal" yang berisi kumpulan hasil karya siswa yang terdiri dari

1. Hasil proyek, penyelidikan, atau praktik siswa, yang disajikan secara tertulis atau dengan penjelasan tertulis.

2. Gambar atau laporan hasil pengamatan siswa, dalam rangka melaksanakan tugas untuk mata pelajaran yang bersangkutan

3. Deskripsi dan diagram pemecahan suatu masalah, pada mata pelajaran yang bersangkutan

4. Laporan hasil penyelidikan tentang hubungan antara konsep-konsep dalam mata pelajaran atau antar mata pelajaran

5. Penyelesaian soal-soal terbuka

6. Hasil tugas pekerjaan rumah yang khas, misalnya dengan cara yang berbeda dengan cara yang diajarkan di sekolah atau dengan cara yang berbeda dari cara pilihan ternan-teman sekelasnya.

7. Laporan kerja kelompok

8. Hasil kerja siswa yang diperoleh dengan menggunakan alat rekam video, alat rekam audio, dan komputer.

Selanjutnya, tim pengabdian mengadakan pendampingan tutorial penggunaan seesaw kepada peserta. Hal ini dilakukan agar mereka benar-benar paham terkait penggunaan seesaw sebagai penilaian pembelajaran digital.

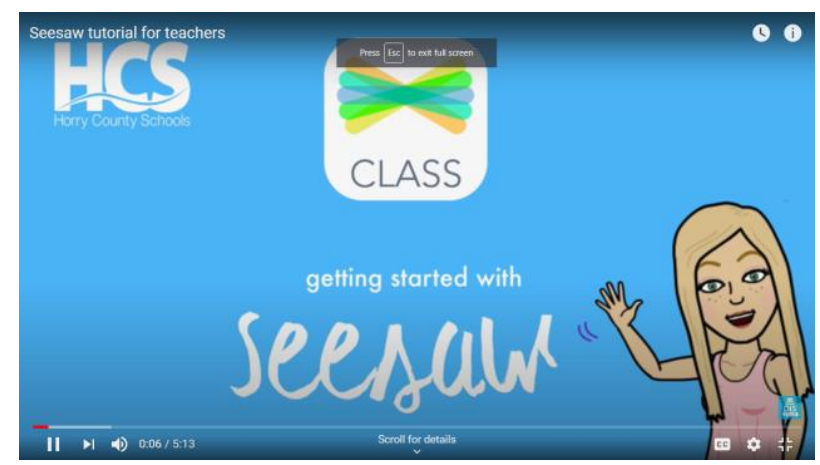

Gambar 3. Tutorial penggunaan seesaw

Di samping itu, ada beberapa hal yang perlu diapresiasi dalam kegiatan ini. Pertama berkaitan dengan antusias peserta untuk mengikuti pelatihan ini. Keantusiasan guru dalam mengikuti kegiatan pelatihan mencapai $95 \%$. Hal ini dikarenakan para peserta pelatihan sangat membutuhkan informasi dan pelatihan cara menerapkan penilaian berbasis digital. 


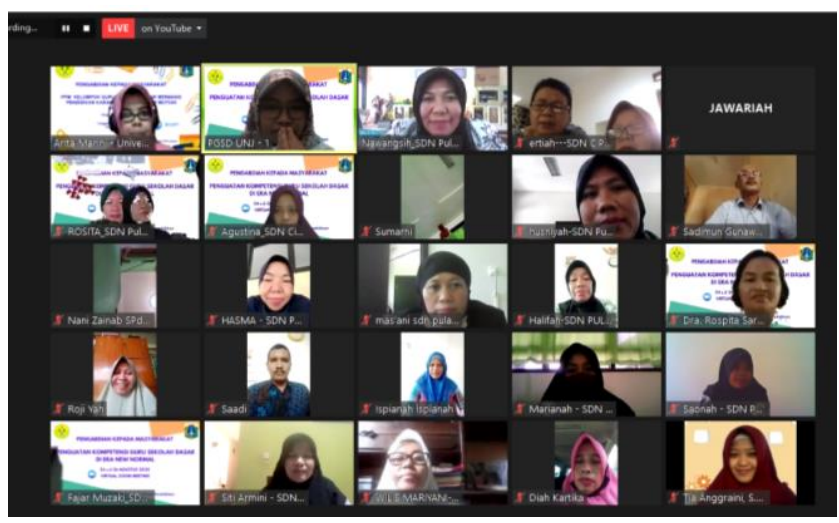

Gambar 4. Foto bersama peserta pengabdian masyarakat

Dengan demikian, pelatihan mengembangkan digital assessment ini sangat dibutuhka oleh seluruh guru sekolah dasar khususnya di wilayah kepulauan Seribu. Seperti yang kita ketahui penilaian yang objektif dapat meningkatkan kualitas pembelajaran. Untuk menjadikan objektif maka penilaian harus disusun secara autektif. Penilaian tidak hanya dilakukan di akhir pembelajaran saja melainkan juga dapat dilakukan selama proses pembelajaran.

Didukung dengan pernyataan Charin yang menunjukkan bahwa, "Authentic assessment is an alternative approach which stresses natural learning and can genuinely develop learners" (Charoenchai et al., 2015). Dalam hal ini lebih ditekankan pada proses belajar yang disesuaikan dengan situasi dan keadaan sebenarnya, baik itu di dalam kelas maupun di luar kelas. Suatu penilaian dianggap autentik ketika guru langsung menguji siswa dengan tugas intelektual yang terpercaya. Hal ini sejalan dengan pendapat yang disampaikan oleh Nitko \& Brookhart bahwa arti kata autentik dalam penilaian autentik di sini adalah menyajikan tugas secara langsung kepada peserta didik yang berarti bagi pendidikan mereka sehingga bermakna (Ferita \& Retnawati, 2017). Berdasarkan pernyataan di atas menunjukkan bahwa pada penilaian otentik, peserta didik diarahkan untuk melakukan sesuatu dan bukan sekedar hanya mengetahui sesuatu, disesuaikan dengan kompetensi muatan pembajaran yang diajarkan. Dengan demikian, pada penilaian otentik, tidak hanya difokuskan pada aspek kognitif, tetapi juga pada aspek afektif dan psikomotorik.

Adanya penilaian berbasis digital (digital assessment) dapat memberikan hasil yang objektif sesuai dengan kriteria yang diinginkan guru dan siswa tentunya. Digital assessment juga dapat memberikan motivasi kepada siswa untuk aktif mengerjakan soal secara mandiri dan mendalam. Dan tentunya penilaian jenis ini, dapat dilakukan dimana saja dan kapan saja. Disamping itu, penilaian berbasis online dinilai lebih ramah lingkungan dan mengurangi penggunaan kertas yang notabene kertas dibuat dari penebangan pohon.

\section{Kesimpulan}

Dari hasil uraian di atas, sebanyak $85 \%$ guru telah menguasai dan mampu menerapkan penilaian berbasis digital. Tentunya pencapaian ini cukup baik dan memang membutuhkan proses yang berkelanjutan. Guru harus melek teknologi dan mampu 
beradaptasi dengan zaman dan keadaan. Oleh karena itu, adanya pelatihan ini sangat memberikan kontribusi dan membantu pemerintah dalam memajukan kualitas pembelajaran terutama di masa pandemik ini dan di era 4.0.

\section{Daftar Pustaka}

Alfian, A., Aminah, N. S., \& Sarwanto. (2015). Authentic Assessment Berbasis Scientific Approach Sebagai Implementasi Kurikulum 2013 DI SMP Kelas VII Pada Materi Suhu Dan Perubahannya. Jurnal Inkuiri, 4(3).

Alimuddin. (2014). Penilaian dalam kurikulum 2013. Seminar NAsional Pendidikan Karakter. https://doi.org/10.1038/jes.2014.32

Azim, S., \& Khan, M. (2012). Authentic assessment: An instructional tool to enhance students learning. Academic Research International, 2(3), 314-320. http://ecommons.aku.edu/pakistan_ied_pdcc

Charoenchai, C., Phuseeorn, S., \& Phengsawat, W. (2015). Teachers 'development model to authentic assessment by empowerment evaluation approach. 10(17), 2524-2530. https://doi.org/10.5897/ERR2015.2243

de Sam Lazaro, S. L. (2017). The Importance of Authentic Assessments in Eligibility Determination for Infants and Toddlers. Journal of Early Intervention, 39(2), 88-105. https://doi.org/10.1177/1053815116689061

Ermawati, Siti., \& Hidayat, T. (2017). Penilaian autentik dan relevansinya dengan kualitas hasil pembelajaran (persepsi dosen dan mahasiswa ikip pgri bojonegoro). Jurnal Pendidikan IImu Sosial, 271), 92-103.

Ferita, R. A., \& Retnawati, H. (2017). Pengembangan Perangkat Penilaian Autentik untuk Pembelajaran Matematika di Kelas VII Semester 1. PYTHAGORAS: Jurnal Pendidikan Matematika. https://doi.org/10.21831/pg.v11i1.9672

Fitriani. (2017). | 164 Getsempena English Education Journal (GEEJ) Vol.4 No.2 Novemver 2017. Implementing Authentic Assessment of Curriculum 2013: Teacher'S Problems and Solusions, 4(2), 164-171.

Gaylord-Opalewski, K., \& O'Leary, L. (2019). Defining Interactive Virtual Learning in Museum Education: A Shared Perspective. Journal of Museum Education, 44(3), 229241. https://doi.org/10.1080/10598650.2019.1621634

Hodgman, M. R. (2014). Using Authentic Assessments to Better Facilitate Teaching and Learning: The Case for Student Portfolios. Journal of Studies in Education, 4(3), 59. https://doi.org/10.5296/jse.v4i3.6149

Holliday, W., Dance, B., Davis, E., Hedrich, A., \& Lundstrom, K. (2015). An Information Literacy Snapshot: Authentic Assessment across the Curriculum. https://doi.org/10.5860/crl.76.2.170

James, L. T., \& Casidy, R. (2018). Authentic assessment in business education: its effects on student satisfaction and promoting behaviour. Studies in Higher Education, 43(3), 401-415. https://doi.org/10.1080/03075079.2016.1165659

Kartowagiran, B., \& Jaedun, A. (2016a). Model Asesmen Autentik Untuk Menilai Hasil Belajar Siswa Sekolah Menengah Pertama (Smp): Implementasi Asesmen Autentik Di Smp. Jurnal Penelitian Dan Evaluasi Pendidikan, 20(2), 131. https://doi.org/10.21831/pep.v20i2.10063 
Kartowagiran, B., \& Jaedun, A. (2016b). MODEL ASESMEN AUTENTIK UNTUK MENILAI HASIL BELAJAR SISWA SEKOLAH MENENGAH PERTAMA (SMP): IMPLEMENTASI ASESMEN AUTENTIK DI SMP. Jurnal Penelitian Dan Evaluasi Pendidikan. https://doi.org/10.21831/pep.v20i2.10063

Larkin, T. L. (2014). The Student Conference: A Model of Authentic Assessment. International Journal of Engineering Pedagogy (IJEP), 4(2), 36. https://doi.org/10.3991/ijep.v4i2.3445

Noor, M., Yusoff, N. M., \& Noor, M. (2016). Improving Process Writing with the Use Authentic Assessment. 5(3), 200-204.

Susani, R. G. (2018). THE IMPLEMENTATION OF AUTHENTIC ASSESSMENT Indonesian Language Education and Literature Study Program. 11(1), 87-92.

Villarroel, V., Bloxham, S., Bruna, D., Bruna, C., \& Herrera-seda, C. (2017). Assessment \& Evaluation in Higher Education Authentic assessment: creating a blueprint for course design. Assessment \& Evaluation in Higher Education, 2938(December), 1-14. https://doi.org/10.1080/02602938.2017.1412396

Wiggins, G. (1990). The case for authentic assessment. - practical assessment, research \& evaluation. Practical Assessment, Research, \& Evaluation, 2(2), 1-3. http://pareonline.net/getvn.asp?v=2\&n=2 